\title{
Потенціал методів письмового інтерв'ювання для дослідження ціннісних аспектів свідомості
}

\begin{abstract}
Анотація. Роботу присвячено з'ясуванню можливостей письмового інтерв'ювання щзоо дослідження аксіологічних аспектів свідомості людини. Аналізуються принципи проведення інтерв'ювання, які дозволяють ініціювати пробудження активної рефлексї опитуваним свойх уявлень ціннісного плану. Сформульовано й аргументовано переваги опитування у формі інтернет-листування щзодо питань екзистениійного плану: письмовий формат відповіді, можливості комп'ютерного «нелінійного» редагування, більша свобода маневру при комп ютерному листуванні, особливості сприйняття віртуального простору, щзо сприяють більш вільній комунікації, залучення опитуваного у наративну практику у письмовій формі. Аргументовано використання методики змішаного (усно-письмового), «розірваного», поступового, гнучкого, почасти прихованого, триваючого інтерв 'ю, в результаті чого можна отримати «керований» діалогічний розірваний наратив. Обговорюються переваги застосування такої методики у виховному і навчальному прочесах.
\end{abstract}

Ключові слова: інтерв'ю, інтернет-листування, опитування, аксіологічний аспект, наратив.

Постановка проблеми. Виходячи 3 базового принципу наративної психології про те, що особистість не тільки розуміє себе за допомогою мови, а й конструює себе у мовленні $[1 ; 2 ; 3 ; 4 ; 5 ; 6]$, а наратив втілює і відображає базові життєві концепції людини, у тому числі його «Я-концепцію», можна припустити, що спеціальна організація мовлення може зосередити людину на певних аспектах іiі досвіду, викликати рефлексію того, що досі не усвідомлювалось або не артикулювалося людиною, i в результаті призвести до актуалізації певних аспектів свідомості і самосвідомості. Під час проведення опитування відносно особистісного зростання $[8 ; 9 ; 10 ; 11]$ ми звернули увагу на те, що деякі засоби проведення опитування виступили чинником «пробудження» рефлексії ціннісних аспектів самосвідомості опитуваних. Гіпотеза, що була покладена в основу даного дослідження, полягає в тому, що такими чинниками $є$ письмова форма опитування (через електронне листування) і пролонгований у часі діалог з опитуваним. Аналізу цієї проблеми і присвячено дану роботу.

Мета роботи полягає у з'ясуванні можливостей письмового інтерв'ювання щодо дослідження аксіологічних аспектів свідомості людини. Ми вважаємо проведення такого аналізу важливим з огляду на актуальність завдання пробудження і розбудови «вершинного» у людині (за терміном Л.С. Виготського) - тобто значущістю проблеми особистісного розвитку і зростання людини. Саме на цьому акцентує робота, що презентується. Особистісне зростання і розвиток грунтуються на засвоєнні особистістю нових цінностей, зміні ціннісної структури особистості. Це стосується різних вікових категорій, оскільки особистісне зростання і розвиток не обмежені віковими рамками. Ціннісний компонент $\epsilon$, на наш погляд, найвагомішим у структурі особистісних складових процесу розвитку особистості, а досліджень аксіологічного аспекту уявлень людини, зокрема в контексті особистісного зростання - тобто 3 підключенням діахронічного виміру, практично нема.

Предметом дослідження $є$ принципи проведення опитування, анкетування, інтерв'ювання, які дозволяють ініціювати пробудження активної рефлексії опитуваним своїх уявлень ціннісного плану. Незважаючи на інтерес сучасних дослідників до всього спектру проблем особистісного розвитку і зростання та на численність методичних матеріалів 3 «глибокого інтерв'ю», нам не зустрілися дослідження, 
які б констатували й акцентували потенціал письмового пролонгованого інтерв'ювання 3 точки зору екстеріоризації ціннісних аспектів свідомості людини.

Використання як об'єкту дослідження індивідуального наративу особистісного зростання дає можливість «доторкнутися» до цієї невловимої абстрактної речі. Завдання опитування, проведеного нами раніше через електронне листування, полягало у тому, щоб заохотити дорослу людину породити думки 3 цього приводу i бажати ними поділитися. Важливу роль у вирішенні цієї задачі грає діалог (у тому числі і з самим собою) - у діалозі, у практиці спілкування відбуваються два важливих процеси: 1) усвідомлення й осмислення певних ще не оформлених у мовний продукт власних смислових утворень, «добудова» і збагачення раніше вироблених смислів; 2) розуміння аналогічних речей у співрозмовника (якщо він $\epsilon$ ). Саме тому доцільним є опитування у формі інтерв'ю або інтернет-інтерв'ю.

У проведеному опитуванні, матеріали якого стали об'єктом аналізу для даної роботи, з'ясовувалися: уявлення дорослих про можливість і сутність змін в особистості протягом життя людини; думки дорослої людини про особистісне зростання; погляд дорослої людини на те, які життєві обставини сприяють особистісному розвитку, а які, навпаки, йому перешкоджають [8; 9]. Опитування проводилося здебільшого у письмовій формі (через інтернет-листування) у групі дорослих людей різного віку переважно «інтелігентних» професій (близько 100 дорослих, більше половини 3 них - жінки). Обставини набуття особистісного досвіду, що стали рушійною силою для особистісного зростання, виявлялися самим суб'єктом під час ініційованої інтерв'юером рефлексії, наративізувалися і в такому вигляді ставали об'єктом аналізу дослідником. Основним методичним засобом було поступове нарощування і відтворення «розірваного» наративу кожного опитуваного за матеріалами неодноразових усних та письмових бесід 3 ним.
Поняття «розірваного наративу» було введено нами раніше [7]; розірваний наратив - це зв'язна оповідь, яка має всі ознаки звичайного наративу, але при цьому текстове «тіло» наративу розподілено по іншому, більшому тексту. 3 таким видом наративів часто маємо справу під час проведення інтерв'ювання чи анкетування. Робота 3 матеріалами опитування передбачає «відбудову» розірваного наративу за допомогою спеціальних методик обробки, «витягування» і «склеювання» фрагментів наративу, відбудову його по краплинках. Коли йде робота 3 опитуваним «сесіями» - інтерв'ювання, пред'явлення тій самій людині анкети за анкетою, 3 уточненнями і доповненнями з ії сторони, цей метод незамінний. Його застосування дозволяє отримати могутній об'єкт дослідження, який містить масу інформації про особу, його «Я-концепцію», «рамку», через яку він бачить світ, інтерпретує події, організовує свій досвід. Такий наратив сам як такий може бути: а) предметом дослідження (це $\epsilon$, по суті, мовна модель «Я-концепції», аналіз якої може дати можливість перейти на концептуальний рівень); б) знаряддям дослідження інших, більш прихованих психологічних властивостей суб'єкта, тобто може бути і тим, щзо досліджуємо, і тим, як досліджуємо, і тим, для чого ми це робимо.

Опрацюванню отриманих при опитуванні «розірваних наративів» передувало виявлення й упорядкування множини смислів, 3 яких у сукупності складаються поняття «особистісний розвиток» і «особистісне зростання» у сучасній психології, — як «бази» для проведення аналізу розуміння особистісного розвитку і зростання опитуваними [10]. Виявилось, що «накладення» цих двох множин достатньо суттєве. Це означає, що «змістовне», концептуальне наповнення індивідуальних дискурсів особистісного розвитку і зростання суттєво сформоване й орієнтоване на прийняте у соціумі розуміння цих понять, а відсутність прив'язки й апеляції до свого індивідуального досвіду тільки підтверджує його «віртуальний» характер. Перелічимо основні смислові ком- 
поненти, 3 яких складається «сукупний» дискурс «особистісне зростання» наших опитуваних: засвоєння «буттєвих» цінностей; націленість на пошук смислу життя; розвиток самосвідомості; усвідомлення себе як особистості; потреба у самоактуалізації; концентрація на меті; етичні та моральні норми; вищі переживання; спрямованість на творення; соціальна зрілість; певні життєві вміння та рівень інтелектуального розвитку; розвиток певних особистісних рис i вольових якостей. Розкриємо більш детально останні два компоненти, адже це цілі «букети» смислів:

1) життєві вміння, що супроводжують розвиток особистості, - це визначення цілей, стратегічних напрямків, пошук нових схем вирішення проблем, навички та вміння спілкування, вміння і готовність до розв'язання конфліктів, рівень інтелектуального розвитку тощо;

2) особистісні риси, що цінуються у людській спільноті і визначають статус людини у соціумі: чесність (відвертість, щирість, автентичність); доброта, милосердя; усвідомленість (реактивність, жвавість, інтерес); свобода (спонтанність, відкритість); довіра (віра); емпатія; здатність до поваги; здатність до розуміння; непатерналізм; лідерські якості; незалежність (в тому числі внутрішня незалежність від обставин, оточення, влади, соціуму, статусу, стану здоров'я тощо); твердість позиції; альтруїзм; несхильність до міфологізованості; готовність до ризику; самостійність; уміння «тримати удар» життєвих обставин, стійкість; незламність, непохитність у своїй націленості «мати задачу в голові» за будь-яких обставин (не упертість!); володіння собою, стримування власних імпульсів; комунікативність; критичність (в тому числі і до себе); здатність виражати почуття; здатність направляти і вести за собою; турботливість; допитливість, цікавість до всього нового; вольові якості, усвідомлена протидія обставинам.

Зрозуміло, що опитувані не вживають саме такі терміни; ми вважали за можливе вбачати у їхніх висловлюваннях відповідні смисли тільки у випадках, які не допускали іншої трактовки.

Різні аспекти проведеного дослідження аналізувалися у ряді наших публікацій [8; 9; 10]. Наразі нас цікавлять особливості використаного методу опитування, оскільки він дав потужний ефект для отримання глибокого занурення опитуваним у досить тонку матерію ціннісних смислів, 3 яких складається його досвід і його відповідний дискурс.

Постановка питань інтерв'ю перед опитуваними спонукала більшість 3 них замислитися і висловитися з теми, яка, можливо, більшістю з них ніколи не обговорювалася, - особистісне зростання людини. Спілкування на настільки «піднесену» тему задає ніби інший «жанр» для нарації опитуваного - примушує «підняти погляд у небо» (за образним висловом С.Б. Кримського), переводить обговорення до екзистенціальної площини. Опитування через електронну пошту виявилося здатним дати людині можливість письмово висловити те, що не вписується у жанри усної комунікації, — так, як це відбувалося при листуванні в минулі часи, завдяки чому ми отримуємо епістолярний жанр.

Можна виділити кілька чинників, що сприяли цьому:

1. Письмовий формат відповіді, що дозволяє розвинути думку більш обгрунтовано і повно, ніж це прийнято в усному діалогічному спілкуванні. В результаті опитуваний продукує достатньо «довгий» текст, часто наративного плану (крім випадків, коли опитуваний явно тяжіє до «тезаурусного» типу відповіді за самим складом своєї особистості); письмову відповідь опитуваний пише наодинųi, що дозволяє йому глибше «зануритися» у свою свідомість; породження письмової відповіді відбувається більш уповільнено, ніж артикулювання усної, що теж сприяє більш розгорнутому i повному формату породжуваного тексту; письмова форма для людей, які мають схильність до цього, надає можливість вийти за межі суто конкретної і лаконічної відповіді і, 3 одного боку, заглибитися у надра свого досвіду, 
а 3 другого - піднятися до пафосу «високого штилю» у стилістиці відповіді, тим більше що поставлене в інтерв'ю запитання сприяє такому повороту. Наведемо приклади «високого штилю» 3 наративів, які абсолютно неможливо уявити у відповідях на усні питання: «Постоянная переоценка принципов, расстановка приоритетов»; «Не насильственное («так надо», «долг») и не спонтанное (порыв души) стремление быть милосердным»; "Чем больше проходит времени, тем больще иеним доброту, проснувшиеся души для любви, понимания, терпения, благодарности всему сущему. Солниу за свет, тепло, которое оно дарит каждый день. Небу, звездам... всему, что нас окружает. Богу за то, как трепетно и с какой любовью он растит каждую душу». У проведеному опитуванні частина реципієнтів воліла відповідати усно; в результаті можемо констатувати, що усні оповіді дали більше фактажу, письмові більше рефлексії, занурення, піднесення.

2. Можливості комп’ютерного «нелінійного» редагування: можливість доповнювати і розвивати вже сформульовану думку, робити вставки, зміни, акцентування; можливість зберігати текст відповіді і повертатися до редагування через деякий час; можливість «загострювати» думку, знаходячи найбільш влучні формулювання, тощо.

3. Більша свобода маневру при комп'ютерному листуванні на відміну від звичайного письмового опитування: можливість не вступати у контакт, якщо опитуваний не бажає (просто не відповідати на лист), або відповісти не одразу - опитувач і опитуваний не включені в одну просторовочасову ситуацію, що робить відповідача більш вільним у своєму виборі - можна відповісти пізніше, послатися на зайнятість або взагалі зробити вигляд, що не отримав повідомлення з питаннями, тощо. Опитуваний не посідає чисто «учнівську» позицію, коли тебе посадили і «треба» виконати завдання - дати відповідь; він сам вирішує, буде він це робити, чи ні.

4. Сприйняття віртуального простору як окремого паралельного каналу чи навіть (за звичкою перебування у Інтернет- просторі) як паралельного світу, де діють трохи інші закони перебування: ти сам наодинці зі своїм комп'ютером - знаряддям текстоутворення, i, в той же час, у контакті, діалозі з безліччю людей; на твою репліку можуть реагувати вже через секунду; відповідь на твої думки може прийти від людей, яких ти ніколи не бачив i, можливо, не побачиш, тощо. Ілюзія контакту 3 цілим світом, з людством загалом сприяе, на наш погляд, виходу на інші горизонти розгляду теми.

5. Залучення опитуваного у наративну практику у письмовій формі (на зразок щоденників, задушевних листів до дуже близької по духу людини). Аналіз результатів опитування дозволив виявити феномен нерефлексованості або слабкої рефлексованості індивідом власного особистісного розвитку. Питання анкети торкалися «потаємного» в людині, глибоко особистісного і прихованого навіть від неї самої. Емпірично викликаний процес осмислення і наративізації затягує особистість у занурення, актуалізацію і текстуацізацію потаємного і тим самим трошки відкриває завісу над ним. Наративна практика такого типу формує систему зняття «особистісного забрала», «щита» [9].

Bce це сприяє тому, що опитуваний (в усякому разі, частина 3 них) має можливість відчувати себе одночасно: як людина XIX століття перед чистим листом паперу наодинці з думками, що можна без поспіху, грунтовно викласти у листі адресату, який тебе зрозуміс; і як інтернет-блогер, який пише всьому світові одразу, не орієнтуючись ні на кого конкретно, і певен, що хоча б когось його текст знайде (а ні — то такий текст служить своїм віртуальним щоденником і підгодовує відчуття самоусвідомленості, самоідентифікації і навіть власної значущості і виключності); і як пацієнт психотерапевта, який витягує з глибин підсвідомості відчуття з далекого минулого, що сформували його теперішнє, переживає і переосмислює їх та отримує від цього болісну насолоду.

Віртуальний простір письмового спілкування, письмових практик, таким чином, 
виконує роль середовища для виникнення i життя дискурсу особистісного розвитку. Спеціально організоване опитування 3 особистісного зростання і самопроектування, яке ініціює певний вид наративної практики у дорослих особистостей різного віку, виступає дієвою технологією самоусвідомлення особистості, а також відіграє роль наративного тренінгу.

Враховуючи всі ці зауваження, ми вважаємо оптимальною для дослідження аксіологічних аспектів свідомості методику зміманого (усно-письмового), «розірваного», поступового, гнучкого, почасти прихованого, триваючого інтерв ю:

- змішане - бажано і переважно письмове; усна форма — для тих реципієнтів, які не хочуть чи не можуть писати за різних обставин. Письмова форма може реалізуватися як переписка через електронну пошту, обмін повідомленнями через інтернет, письмові відповіді наодинці на заздалегідь надрукованих бланках (це менш бажано, бо структура інтерв'ю у такій формі жорстка і незмінна). Усна форма опитування більш гнучка, проте опитуваний позбавлений можливості пролонговано осмислити питання і продукувати глибші відповіді. Найбільш пріоритетні перші дві форми письмового опитування, бо тут діалог послідовно, порція за порцією розгортається у часі, підключається часовий параметр; крім того, у реципієнта нема можливості дізнатися про зміст подальшої частини, навіть про саму iii наявність, і тому наступні питання не зможуть вплинути на зміст і розмір відповіді на попередні;

- розірване - порціями, через різні проміжки часу, з уточненнями, продовженням діалогу доти, доки опитуваний витримає. Діалог потроху вщухає, бо опитуваному набридає напружуватися (розмова вимагає напруженої рефлексивної роботи - це i $є$ мета опитування), або тема його в принципі не дуже цікавить, або немає часу тощо;
- nоступове-змістпорції визначається заздалегідь запланованими «топіками», закладенимиупитання. Топікиінтерв’ю, з яких складається опитувальник, деталізують у досліджуваному об'єкті чи феномені ті аспекти, що цікавлять дослідника, крім того, в них закладено структури для розвитку діалогу 3 опитуваним і отримання наступних фрагментів інтерв'ю. Топіки конструюються експериментатором заздалегідь на основі попереднього аналізу предмету і мети дослідження, проте відтворення опитувальника у конкретному інтерв'ю має індивідуальний характер, список топіків може поповнюватися безпосередньо під час проведення опитування, оскільки сама діалогічна практика вносить багато нових непередбачуваних змістів у конкретний дискурс дослідження; у цьому сенсі опитування $\epsilon$ різновидом пошукового експерименту, а опитувані є рівноправними співавторами результату. Раніше нами було введене поняття «методу співрозмовника» для позначення такого діалогічного опитування, коли не тільки дослідник задає питання, але й опитуваний у відповідь, відчуваючи атмосферу рівноправ'я, може поцікавитися чимось у зв'язку з темою опитування [2; 3], і тим самим внести свій вклад у розбудову структури конкретного наративу;

- гнучке - послідовність пред'явлення топіків визначається розвитком діалогу, тобто залежить від отриманої відповіді на попереднє питання. Опитування такого роду має принципово проективний характер: питання психолога проектує відповідь реципієнта, відповідь проектує подальше питання дослідника;

- почасти приховане - за можливості питання ставляться не «в лоб», а завуальовано, в іншому відволікаючому контексті, про щось, що «покриває» чи «межує» 3 предметом, що цікавить дослідника. Опитування показало, що 
людей, які є свідомими процесів свого особистісного розвитку, зростання чи самопроектування та які охочі це оприлюднити, не так багато. Ще одна причина - питання аксіологічного плану відчуваються людиною як дуже приватні; щоб не була очевидною і не лякала інтервенція у ії внутрішній світ, краще цікавитися думкою опитуваного про досліджувані явища в принципі, апелювати до його досвіду взагалі. На цьому грунтується надія на позитивний результат експерименту (який полягає в отриманні розгорнутого розірваного наративу опитуваного на тему, що нас цікавить);

- триваюче - інтерв'ю триває без обмежень, якщо реципієнт продовжує породжувати свою розгорнуту відповідь.

Особливості спілкування між комунікантами — інтерв'юером і реципіснтом — під час проведення опитування роблять однаково важливими для аналізу і питання інтерв'юера, і відповіді опитуваного, тому об'єктом подальшого аналізу принципово є весь текст інтерв'ю. Обробка матеріалів такого опитування передбачає достатньо деталізований текстовий опис технології, неможливий без гіпотетичних побудов:

- виявлення у тексті ознак, що свідчать про наявність рефлексії реципієнтом об'єкту чи феномену, що нас цікавить;

- аналіз та інтерпретація дослідником уявлень реципієнта на основі цих ознак;

- на матеріалі аналізу будується смислова модель цих уявлень, тобто бачення реципієнтом досліджуваного об'єкту чи феномену.

В результаті застосування такої методики отримуємо текст діалогу, на базі якого конструюємо «керований» діалогічний ро- зірваний наратив. Побудова його дослідником глибинно обгрунтована: такий наратив вербально відтворює екстеріоризацію єдиного внутрішнього уявлення опитуваного, яке - гіпотетично - за певних умов могло б втілитися у такий наратив.

Висновки. Здається слушним спробувати залучити уроки цього дослідження до вироблення методик «пробудження» процесу осмислення екзистенційного плану свого буття учасниками освітнього процесу. Опитування, наближене до проективних методик і за змістом оріснтоване на осмислення опитуваними свого досвіду, може стати тим стимульним матеріалом, яке викличе бажані процеси в опитуваних. Впровадження методики такого типу у виховний і навчальний процеси може сприяти розвитку здатності до переосмислення власного досвіду; зосередженню уваги на ціннісних аспектах свідомості людини; розвитку здатності до рефлексії себе як особистості; розвитку цілеспрямованості і структурованості поведінки; розвитку критичного ставлення до себе й оточуючих; привнесенню ціннісних смислів у свідомість тих учасників навчального процесу, які не мали його у своєму активі до початку застосування методики; розвитку наративної компетентності особистості; розвитку здатності до самопроектування; (опосередковано) розвитку тих мисленнєвих і особистісних якостей, які сприяють вивченню i засвоєнню шкільних знань, зокрема, з гуманітарних дисциплін. Сама форма здається особливо перспективною для використання у дистанційному навчанні. Таким чином, можна вважати, що «проходження» опитуваного через інтерв'ю такого плану може виконати роль певного тренінгу, в результаті якого «запускаються» процеси самовідстеження свого досвіду і моніторинг «фільтра» при отриманні нового.

\section{Список використаних джерел:}

1. Наративні психотехнології / Н. В. Чепелєва, М. Л. Смульсон, О. М. Шиловська, С. Ю. Гуцол. - К. : Главник, 2007. — 144 с. - (Серія «Психол. інструментарій»).

2. Проблеми психологічної герменевтики : монографія / Н.В. Чепелєва, Т.М. Титаренко, М. Л. Смульсон та ін. — К. : Міленіум, 2004. — 276 с. 
3. Проблемы психологической герменевтики / Н. В. Чепелєва, Т.М. Титаренко, М. Л. Смульсон та ін. - К. : Изд-во Национального педагогического университета им. Н. П. Драгоманова, 2009. - 382 с.

4. Соціально-психологічні чинники розуміння та інтерпретації особистого досвіду / Н.В. Чепелєва, Т. М. Титаренко, М. Л. Смульсон та ін. - К. : Педагогічна думка, 2008.

5. Чепелева Н.В. Общая характеристика нарративной психологии / Н. В. Чепелева // Проблемы психологической герменевтики / [Под ред. Н.В. Чепелевой]. - К. : Издательство Национального педагогического университета им. Н.П. Драгоманова, 2009. C. $127-134$.

6. Чепелєва Н.В. Теоретичні засади наративної психології / Н.В.Чепелєва, М. Л. Смульсон, О. М. Шиловська, С. Ю. Гуцол // Наративні психотехнології / М. Л. Смульсон. - К., 2007. - С. 3-37. - (Серія «Психол. інструментарій»).

7. Зарецька О.О. Деякі методологічні зауваження щодо «розірваного наративу» у психогерменевтичних дослідженнях / О.О. Зарецька // Мова і культура (науковий журнал). - К. : Видавничий Дім Дмитра Бураго, 2009. - Вип. 12. - Т. 10 (135). - С. 57-64.

8. Зарецька О.О. Життєві контексти особистісного зростання дорослих / О. О. Зарецька // Розуміння та інтерпретація життєвого досвіду як чинник розвитку особистості : монографія / [за ред. Н. В. Чепелєвої]. — Кіровоград : Імекс-ЛТД, 2013. — С. 141-170.

9. Зарецька О.О. Наративні практики особистісного зростання / О. О. Зарецька // Наукові студії із соціальної та політичної психології / [редакційна рада: М. М. Слюсаревський (голова), В. Г. Кремень, С. Д. Максименко та ін.]. — К. : Міленіум, 2012. — Вип. 31 (34). - C. 81-93.

10. Зарецька О.О. Ціннісні пріоритети в уявленнях людини про особистісне зростання [Електронний ресурс] / О. О. Зарецька // Технології розвитку інтелекту. — Том 1. — №6 (2014). - Режим доступу : http://psytir.org.ua/upload/journals/6/authors/2014/Zaretska_ Olga_Oleksandrivna_Tsinnisni_\%20priorytety_v\%20_uyavlennjah_lyudyny.pdf

11. Зарецкая О. А. Осмысление человеком своего личностного роста (по материалам эмпирического исследования) / О. А. Зарецкая // Личность и ее жизненный мир : материалы Всероссийской научно-практической конференции с международным участием, посвященной 20-летию факультета психологии ОмГУ им. Ф. М. Достоевского (Омск, 3-4 октября 2013 г.) / под ред. Л.И. Дементий. — Омск : Изд-во Ом. Гос. Ун-та, 2013. — С. 65-71.

Аннотация. Работа посвящена выяснению возможностей письменного интервьюирования при исследовании аксиологических аспектов сознания человека. Анализируются принципы проведения интервью, которые позволяют инициировать пробуждение активной рефлексии опрашиваемым своих представлений иенностного плана. Сформулированы и аргументированы преимущества опроса в форме интернет-переписки по вопросам экзистенциального плана: письменный формат ответа, возможности компьютерного «нелинейного» изменения, большая свобода маневра при компьютерной переписке, особенности восприятия виртуального пространства, которые способствуют более свободной коммуникаиии, вовлечение опрашиваемого в нарративную практику в письменной форме. Аргументировано использование методики смешанного (устнописьменного), «разорванного», поступательного, гибкого, отчасти скрытого, длящегося интервью, в результате чего можно получить «управляемый» диалогический разорваный нарратив. Обсуждаются преимущества применения такой методики в воспитательном и учебном nроиессах.

Ключевые слова: интервью, интернет-переписка, опрос, аксиологический аспект, нарратив.

Abstracts. The paper is aimed to consider the opportunities of written interviews in the study of axiological aspects of human consciousness. The principles of interviewing that allow to initiate the awakening of the active reflection of respondent perceptions of their value plan are analyzed. The benefits of the survey on matters of existential plan in the form of online correspondence are formulated and argued: a written response format, the possibilities of computer «non-linear» editing, greater freedom of maneuver in computer correspondence, specifics of the perception of virtual spaces that promote a freer communication, involvement of the respondent in the narrative practices in writing form. Argued the use of methods of mixed (oral-written), «broken», gradual, flexible, partly hidden, lasting interview, whereby it is possible to get a «controlled» dialogical broken narrative. The advantages of using such techniques in the educational and learning process are discussed.

Keywords: interviews, online correspondence, surveys, axiological aspect, narrative. 